\title{
THE HABITUATION OF THE ANCIENT EGYPTIANS AND THE METHODS OF TREATMENT
}

\section{MAHMOUD EL-MOHAMDY ABDELHADY SALAMA \\ MANSOURA UNIVERSITY}

\begin{abstract}
The concept of Habituation in the Culture of societies has been linked to drugs due to the spread of this phenomenon but it's wrong to link the concept of the Habituation only to drug Habituation because there is many different forms of the Habituation like: sex Habituation, alcoholic drinks, internet, food, tv, shopping, violence, and many different forms of Habituation. The concept of Habituation is associating to the idea of losing self-control and drifting behind the desire of achieving pleasure because the addicted person feels a need or a compulsive desire to do something so taking a drug or having sex eventually leads to imbalance in the Feelings and the behavior of the individual and makes him unable to control his actions.
\end{abstract}

KEYWORDS: Habituation, poppy, wine, beer, ancient Egyptian, drugs.

\section{INTRODUCTION}

The Egyptian civilization knew the Habituation such as drug Habituation, beer and wine Habituation and put it in different forms and directories from the Egyptian literature which indicates that the ancient Egyptian society knew Habituation and worked on treating addicts in sanatoriums attached to temples to treat the addicted (patient) under the supervision of what is known as psychologists, which was through psychological and social treatment or sports therapy and rehabilitation.

The word "drugs" is mentioned in the ancient Egyptian language under the name $n h \breve{s}$

tos $=$

The ancient Egyptian extracted these drugs from the poppy plant for using it in medicinal purposes, but he maybe used it for other purposes by taking it to create a mode or some feelings.

This research shows the types of drugs that the ancient Egyptian has been addicted to in terms of their use of poppy and its fruit, as well as his Habituation to alcoholic drinks such as wine from all kinds and beer in which the ancient Egyptian was excelled. 
This research will deal with three topics as follows:

- The first topic is the definition and the sorts of Habituation in ancient Egyptian life.

- The second topic shows psychologists.

- The third topic reviews the methods of treating Habituation and compares it with modern treatment.

- Results and recommendations.

THE FIRST TOPIC: THE DEFINITION AND THE SORTS OF HABITUATION IN ANCIENT EGYPTIAN LIFE

Habituation is the frequent use of psychological substances (drugs) to reach a psychological state and sometimes an organic condition resulting from the interaction with the narcotic substance to a degree at which the addicted person tends to increase the dose of the taken drug, and he is controlled by a compulsive desire that maybe force him to get the needed psychological substance by any way.

It may happen a Habituation that isn't necessarily considered dangerous or harmful like the psychological state that results from drinking coffee, tea and tobacco and this type of Habituation isn't our interest in this research, but habituation resulting from drug and alcohol abuse.

Alcohol is considered the main heady drink throughout the ages in Egypt and this is what the recorded evidences confirms to us in ancient Egypt as it was available in the ancient Egyptian society like beer, wine and the poppy plant.

Drinking alcohol frequently may lead to Habituation and it isn't necessarily affect all alcohol drunks as it depends on the number and the time of drinking and the state of drinking alcohol a lot is called alcoholism although it is difficult to define alcoholism or alcoholic drinks but it indicates a chronic ${ }^{1}$

Alcohol appeared in ancient Egypt throughout the historical ages, and this is confirmed by recorded evidence and historical evidence in ancient Egypt. Drinking alcoholic beverages was available in ancient Egyptian society and therefore was one of the intoxicants that leads to Habituation in ancient Egypt ${ }^{2}$.

The most important forms of Habituation that appeared in ancient Egypt by consuming alcoholic drinks such as beer, wine or drinking cannabis such as poppy, which was widespread in ancient Egypt and that led to Habituation and accustomed to drinking them, which had a negative

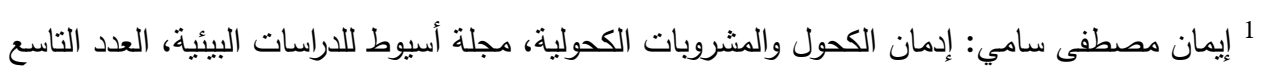

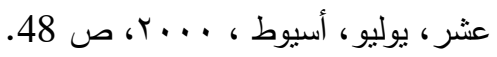


impact on the reach of those intoxicants that he always enjoyed Never get rid of the habitual condition that he always used to drink.

\section{BEER : \& $\triangle$ ¿}

Beer appeared in ancient Egyptian life and was known as Hnqt in the ancient Egyptian language and the ancient Egyptian excelled in making beer. The beer drink is considered the oldest drink in the world and whose origin originated in Egypt back to the period 3400 BC, has become the first and basic drink in ancient Egypt and was used barley plant to make beer ${ }^{3}$.

Beer was one of the important drinks to the ancient Egyptian and can be described as the first popular drink, because all historical evidence confirms that the ancient Egyptian used to consider his national food consisting of beer and bread, especially for a large segment of the Egyptian people ${ }^{4}$.

Lower Nubians make in Egypt at the present time. It contains a large amount of brewer's yeast and the amount of alcohol in it ranges from $6.2 \%$ to $8.1 \%$.sundae drink is a heady drink, and people of the lower class often drink it ${ }^{5}$.

Many of the scenes of drinking beer and other intoxicating substances in tombs, temples, and the enormous amounts of wine and beer which was found in the excavations indicate the Egyptians' fondness to drink alcohol, especially during holidays, ceremonies and banquets ${ }^{6}$.

But it should be noted that drinking alcohol was not common among all classes of the Egyptian society as for beer, it was widely known, also the wise "Anny" describes a good mother is the mother who used to prepare three loaves of bread and a bottle of beer daily for her son who attends school.

As for the soldiers, they used to drink beer irregularly, and they were waiting the end of the wars until beer was distributed to them in another account it was mentioned that the soldiers were given a daily ration of beer sufficient for them to lose their mind $^{7}$.

${ }^{3}$ Lutz, H., Viticulture and Brewing in the Ancient Orient, Leipzig, 1992, p. 85

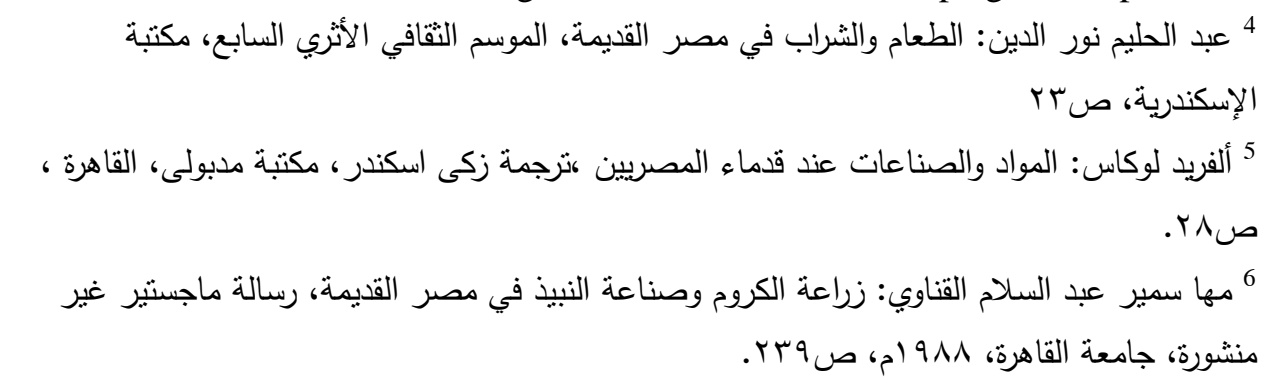

${ }^{7}$ Op. cit., p. 86. 
And about the women of the common people, they were consuming unlimited quantities of alcohol due to the Egyptian community's acceptance of the widespread drinking of alcohol in banquets. Herodotus states that the priests had a daily share of beer with the food provided to them also Plutarch spoke about the amount of wine that the priests were consuming, and they only consumed small amounts, but in the times of devotion and learning they fast completely ${ }^{8}$.

But despite this caution, however, in some festivals and holidays (such as the valley feast) they got drunk and drunk like others, besides some texts were found that some priests buzzed and depicted Rameses III setting up the priests of his funeral temple in the city of Habu on the occasion of his taking over a place to drink beer and donated them 30 (sn) (beer pot) of the very strong type the king gave to his priests to make them happy and refresh them ${ }^{9}$.

And about the kings, the danger of the responsibilities of the position required that the kings do not drink too much in order to preserve the prestige of the holy property, but there were some kings drink a lot till drunkenness like Khufu and Menkaure and Sahure, wine is also among the rituals of coronation ceremonies and festivals as it makes the soul feel joy and euphoria also King Akhenaten appeared in some scenes of the Amarna tombs while drinking alone or with his family ${ }^{10}$

To prepare the bread beer, the wheat spikes or barley were cleaned, then the pulses were hammered with large pestles in a deep mortar like bowl, then being wet with water for a day, until they were inflated and added to the yeast then a man or a woman kneads it and formed it into loaves which its face turns into red with the loaf heart remaining raw and then the loaf is cut into four parts thrown into a container with grape water and left until brewing and when it reaches the required fermentation level it is placed in a basket like a filter under a large pot of pottery, and kneaded With hands, the juice comes out of the basket where it gathers in the Vase Here the liquid begins to be the required beer (fig. 1) ${ }^{11}$.

2. WINE: $4 \longrightarrow$ irp

Wine was known in ancient Egypt as irp and the ancient Egyptians drank wine alongside beer, and the wine was the drink of rich people and wine was the most important spiritual drink for the ancient Egyptians, although

${ }^{8}$ Op. cit., p. 301.

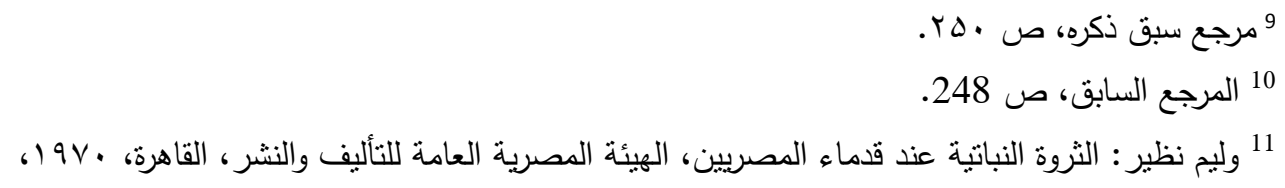


they had other and varied wines such as grape wine, palm wine, dates wine and pomegranate wine ${ }^{12}$.

The earliest reference to the definition of wine as irp, is from the reign of the third family, even though the hieroglyphic sign indicating the winepress of grapes was used during the reign of the first family. There are also a well-known wine pots from that era ${ }^{13}$.

Ancient Egypt knew more than 24 types of wine, which was made from grapes, pomegranates, dates and honey, and its forms were white, black, and red also the finest wines were made in the Delta region, next to the Canopic and Mendesian branch of the Nile ${ }^{14}$.

The multiple scenes of drinking wine and other intoxicating substances in tombs, temples, and the enormous amounts of wine and beer found in the excavations indicates that the Egyptians' passion for drinking wine.

Screams of criticism came out loud against drinking and the warnings of going badly accentuated, and this critical tone may reflect the increasing social awareness to face the excessive consumption of alcoholic drinks and the texts that were taught to students to preserve them with many of these sermons and warnings ${ }^{15}$.

As the wise Anny advising his son Khanshotep "do not risk by drinking as they will say get away from this fool, and if someone comes looking for you and interrogates you he will find you laying on the ground like a little boy $^{16}$.

The workers were reaping the ripe grapes and gathering them in baskets carrying to the winepress, which is a tall low basin over which wooden supports are raised above man height and the basin was filled with grapes, then five or six men raised their arms to grab the upper beams of the pillars of this wooden structure and mash the grapes with their feet ${ }^{17}$. It was a picture on the walls of the tomb of "Abi" from the era of the New Kingdom, representing the reaping of grapes and its time in preparation for making wine, squeezed wine was flowing in channels into a large basin (fig. 2).

The abundant availability of alcoholic drinks led to misuse and overuse, which led to individuals suffering from complications from alcoholism, tombs and papyri, as well as the impressions of foreign visitors, clearly

$$
\begin{aligned}
& 12 \text { وليم نظير : المرجع السابق، صسبـ.. }
\end{aligned}
$$

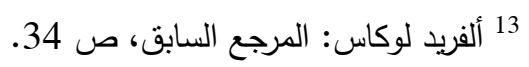

${ }^{14}$ H. Kama 1, Dictionary of Pharaonic Medicine, Cairo, The National Publication House, 1967, p. 498.

${ }^{15}$ Faulkner, FCD, p. 28.

${ }^{16}$ Lichtheim, M., Ancient Egyptian Literature, VII, p. 137.

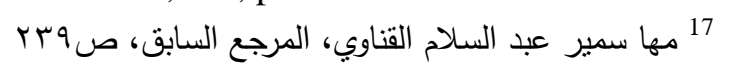


demonstrated the seriousness of the increased alcoholism that causes poisoning, some demotic writings describe the boxing match for drunkenness as a fight to win wines, another view in the tomb of Antif no. 155 in Thebes shows two of the slaves who carried their master who was excessive in drinking wine and was completely drunk and followed by another three slaves carrying their master over their heads(fig. 3) and another view from the tomb of Neferhotep in Tiba no. 49 with the kindness of a woman sitting cross-legged in severe vomiting shows that she is suffering a lot due to drink wine(fig. 4), another view from the tomb of Amenemhat no. 53, a drawing for a very sick man getting up what inside his stomach and there is a friend sitting on a bench next to him, finally, a view from Antif's tomb in Tiba (fig. 5)shows the guard of the wine store there as a result of flying fumes from the puppies and he difficultly notice that there were knocks on the door of the storehouse of a man telling his colleague that he is asleep and his colleague suspends that he is heady by wine ${ }^{18}$.

Drunks were not limited to peoples only, but the gods were intoxicated as well, in one of the songs, Hathor was described as a woman who sits drunk in front of her house and her hair strands hanging from her beautiful chest ${ }^{19}$.

Also about Theophrastus, approximately 300 B.C., it provides us with a wonderful description that explains the excessive consumption of alcohol and its negative impact, and he describes the case of an Egyptian woman who drank a large amount of wine until she got crazy and she hugged and kissed every man she met, then her laughter and singing turned into a state of extreme anger and sadness, and she quarreled with anyone until her situation condition was in a state of complete chaos, and from the severity of the condition that everyone had with her at home he takes precautions from her because of being afraid, then after that she became very sad until she entered into a state of mourning and lamentation with her dead relatives and friends in form of a song until she fell asleep and woke up from her drunk ${ }^{20}$. Ostraka of one of the Ramesside students remains the best pieces describing the drunk state of humiliation, helplessness and the getting away of family and friends of the addicted person, and it founded in two curtains Anastasi\&Salleir " I was told that you left the writing, and

$$
\begin{aligned}
& 18 \text { نجيب متري : آداب قدماء المصريين وديانتهم ، دار المعارف ، القاهرة ، ص اب آ. } \\
& 19 \text { مها سمير عبد السلام: مرجع سبق ذكره، ص دئ : } 291 .
\end{aligned}
$$

${ }^{20}$ Hussein, M., Mental Health and Psychological Medicine at the time of Pharaohs M.Scr.

Cairo, 1993, p. 136 
that you are going lightly, and hanging around on the streets (literally from street to street).

- The smell of beer spreads when there is a beer that keeps you away from people and makes your soul go astray

- You are like a crooked paddle in a boat that can't be driven to any side, you are like a temple without gods, like a home without bread - i found you climbing a wall after you broke the store, People get away from in front of you, after you put them in a surgeon, really i hope that you know that wine is a sinner.

- You have sworn not to drink beer, so do not put a beer jar in your heart and forget the wine drink.

- You were taught to sing on the oboe, sing the flute, sing the harp, and sing

- While you are sitting on the street, prostitutes revolve around you while you stand still - now you are sitting in front of the girls while you are wet with paint and wreath flowers around your neck.

- You knock on your stomach, stumble and fall on your stomach while you are stained with fouling ${ }^{21}$.

From the above, it is clear to us that the ancient Egyptians considered wine to be a poison to drink it robs the mind and harms health and for this the voices of the wise came out warning against drinking excessive alcohol

\section{OPIUM}

The ancient Egyptian, while trying to select everything that is edible, came to know the effects of certain plants on the organs of his body, he has begun practice to treat himself form certain diseases and this knowledge contributed to the invention of the science of herbal therapy as the ancient Egyptians took advantage of hundreds of plant, animal and mineral drugs in the treatment, among these drug plants was the opium plant, which is the most important and the most dangerous of these herbs, and was called the poppy plant or the father of sleep ${ }^{22}$.

It came in the Berlin dictionary wb. IV, 444 the word Spn is a plant that has been used medicinally and gives a fruit called Spnn. It places a question mark and says it is possible that this plant is the father of sleep (the poppy plant)? Then he says about the fruit that it may be the fruit of the father of sleep (poppy) and used to mitigate children, it is known that the French word Opuim, which means dry plant succulent, is the syphilitic

${ }^{21}$ Maha Samir Abdul Salam: Previous reference ، p239

$$
22 \text { وليم نظير، مرجع سبق ذكره، ص rYV. }
$$


origin of the Arabic word "opium", which is derived from the Greek origin OPION, which means the plant sap ${ }^{23}$.

The poppy plant has been called the opium plant in relation to the opium extracted from it, and its names in the various languages are similar (Greek, Coptic, Hebrew and ancient Egyptian), and it is likely that the last syllable of the Egyptian word sh epen which is epen is very similar to the Greek and Hebrew name and perhaps the letter sh is in the chest The word (shows a pool of water) is overloaded because the Egyptians used to grow it around the ponds in their gardens, as can be seen, and it also indicates to us that the origin of the plant is not Egyptian (fig. 6).

His name, Spn, appeared in the Ebers papyrus and Edwin Smith as a painkiller and made from it puffs placed on wounds as a strong anesthetic and as a medicine for drinking to calm the nerves of children who cry a lot and these are the same things in which the poppy plant is used now in modern medicine field ${ }^{24}$.

This plant was not basically Egyptian but it has an eastern origin as it entered Egypt in an unknown period in its ancient history and its cultivation was still permitted until 1914 AD it is also called Numan and Abu Al-Noum, and it is an important element among plants of great economic importance in Egypt during the Greco-Roman era ${ }^{25}$.

There is no doubt that, since the dawn of history, man used some plants that grow in nature in order to bring out a kind of change in his psychological state and he was aiming at that in order to enjoy feelings of pleasure and euphoria, in the other hand he was aiming in other cases to alleviate his pain and treat many diseases that he suffers from. The oldest poppy plant from which opium is extracted. The Sumerian civilization has known from seven thousand years BC the properties of anesthesia in the opium plant and used it in medical treatment ${ }^{26}$.

Some inferred the knowledge of the ancient Egyptians of the poppy plant and the extraction of opium from it from the inscriptions that were found in their tombs, for example the earrings consisting of seven useful plants, such as a poppy plant (fig. 7).

Poppy also mentioned in ancient Egyptian literature, like at the beginning of songs of pleasures:

\footnotetext{
${ }^{23} \mathrm{~Wb} . \mathrm{IV}, 444$

24 حسن كمال : الطب الدصرى القديم ، الجزء الاول والثانى، المؤسسة المصرية للطباعة والنشر ،

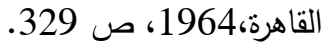


"Poppy flower in the garden and I hold your wreaths and when you come back drunk and lie in your bed I wipe the dust of your feet ${ }^{27}$.

From the foregoing it becomes clear to us that the ancient Egyptians used to drink beer, wine and also the use of cannabis in the treatment of diseases, analgesics and prescriptions, and it may be taken alone to reach the secret of meeting the gods, and this is the case that leads to hallucinations and symptoms of these Habituations appeared and those alcoholic drinks and cannabis appeared in the statue of Amenhotep the Third which is shown in (fig. 8).

\section{THE SECOND TOPIC: PSYCHOLOGISTS AND THERAPIST}

The ancient Egyptians believed that every disease is one of the malignant spirits that overwhelms the bodies by its ferocious force so diseases occurred, and that evil intensity towards us should be met with the strongest effect which makes it expires and heals then the patient will be ok. They used to have two methods in treatment, the first one of them was the spiritual effects in which they believe and it was exclusive for some priests and magicians ${ }^{28}$. The second way was to use the usual medical drugs to request healing, because the god Idahi the chief of magicians has recommended to his people the influence of its secret and that it is one of the properties felt by hand. Its usefulness is more and more beneficial than these spiritual forces, which wasn't always effective ${ }^{29}$.

And since the disease was mainly due to a soul, even if it is evil, then the medicine must logically come from an individual who has a special connection to spirits or deities, and the patient's condition was the guiding factor in the process of calling the doctor, the wizard, or the priest, if the situation is psychological or mental, such as hallucinations, madness, or polluting them, as they say, the patient's family resort to magicians or priests because they believe that such diseases are spiritual in origin.

Herodotus mentioned on Egypt: "There was an eye doctor, another for hands, teeth, abdomen, and unknown diseases." however, he did not mention the presence of a doctor who specializes in mental or psychological diseases that work to treat Habituation and symptoms that were similar to hallucinations and disturbances called unknown diseases. Nevertheless, it is likely that the magician in ancient Egypt was in fact the

$$
\begin{aligned}
& 27 \text { كلير لالويت:نصوص مقسة ونصوص دنيوية من مصر القديمة ، ترجمة: ماهر جويجانى، المجلد }
\end{aligned}
$$

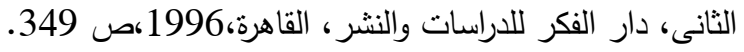

$$
\begin{aligned}
& 28 \text { يوليوس جيار ، لويس ريتر : الطب والتحنيط في عهر الفراعنة، تعريب أنطوان زكري، مكتبة مدبولي، }
\end{aligned}
$$

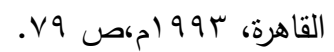

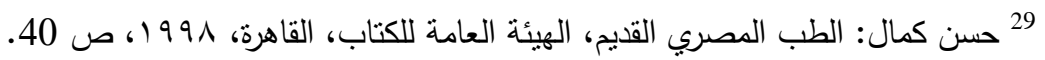


psychiatrist, and the psalmist also had the same role in treating these Habituations ${ }^{30}$.

\section{The Magician $₫ 3 w$ 只}

The magician's choice was subject to precise rules in view of the seriousness of the powers he controlled, and for this, his choice required careful selection and thorough examination so the candidate was chosen from his childhood against the background of being a magician's descendant, or to carry some badges on his body, or to suffer from one of the sacred diseases such as epilepsy or hysteria, or to have a miracle occurred to him in his life, and Tibetan monks still take such considerations in electing their priesthood the magician used to be grown up with a special education, isolated from the rest of the people, surrounded by barriers that prohibited his food, clothes, and sexual relations.

There is no doubt that this cruel isolation that the magician used to be unique to, and the tremendous assumptions that he was paying for the price given to him by the ability he had endowed with his powers.

His senses are inflamed and deepen his belief that he distinguished from his brothers and that the gods specialized him with distinct gifts and supernatural abilities ${ }^{31}$.

The magician's psychological state had a weight adjusting to his physical condition, as he was characterized by a delicate sensitivity, almost close to hysteria and when the talisman was not at the beginning of its matter according to some people's belief that it is the safety valve of the intense desire inherent in the same enunciated in it, imagine him achieving his desire and also the magic movement was not based on the soul's delusion of the occurrence of the desired event by doing the same, which is known as the secret of the word and its meaning among the ancient Egyptians, therefore, the magic work was characterized by violence in pronunciation and action, and the one who brought it felt that he was freed from a tyrant's power, while those around him still acquiesced to it, also the magician, while working and performing magic rituals, he was making his nerves suggestive until they reached a great degree of agitation and tension so it produces a false movements and violent words that may have no meaning, and its role represents a brutal representation ${ }^{32}$.

${ }^{30}$ Ghalloungui, P, Magic and Medical Science in Ancient Egypt, London, 1963, p. 86 .

$$
\begin{aligned}
& 31 \text { بول غليونجي: طب وسحر، مكتبة النهضة، القاهرة، } 999 \text { ام، ص16. } \\
& 32
\end{aligned}
$$


The magician was known as $\check{3} 3 w$ which means magician and the word is derived from the word $\varsigma 3$ which means protection or amulet, and therefore the title is translated into the man of amulets or protector that protects others from risks ${ }^{33}$.

The oldest mention of this title back to the era of the old Kingdom. And about the tasks and the function of the $\mathrm{S} 3 \mathrm{~W}$, it was to make amulets or charms to protect people paragraph No. (854) of the Ebers Papyrus states that the $\mathrm{S} 3 \mathrm{~W}$ is a practitioner of treatment, and also, some doctors from the Middle Kingdom era held the title of S3W "wizard" in addition to doctor at the same time ${ }^{34}$.

The magician's best way was to assure the souls that the patient was guarded by a specific god or group of gods, that is why it must leave it, otherwise it will expose itself to destruction and harm, the god Thoth was considered the first one to write scientific books in magic and its talismans, the magicians were close scientists, mentors, king's writers, dream interpreters, and they tell people about their past, present, and future, and they have the talismans to fulfill peoples' needs and purposes ${ }^{35}$.

The magician had a role in the life house $\left(\mathrm{Pr}-{ }^{C} n h\right)$ as a doctor who has the ability to treat diseases, which are considered actions of the god Sekhmet, so long as magic and magicians were associated with medicine and religion matters, so it was intuitive that the magician should be familiar with the knowledge sciences, especially medicine, and also be from the priest class, in addition to the knowledge of magicians and their vast culture gave them the chance to elevate high ranks in the ancient Egyptian society .

\section{THE RECITED PRIEST WT INPW}

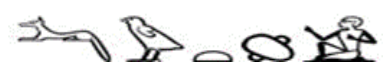

Religion played an effective role in the life of the ancient Egyptian. The belief of the ancient Egyptian in thought and religion was not only a spiritual emotion, but in fact it was also the result of a person's need for a feeling of reassurance and stability ${ }^{36}$.

The titles of some priests show us the extent of their participation in the medical fields in the ancient Egyptian language, and the oldest mention of

${ }^{33}$ Rinter,K., The Mechanics of Ancient Egypt Magical Practice,, Chicago, 1993, p. 51.

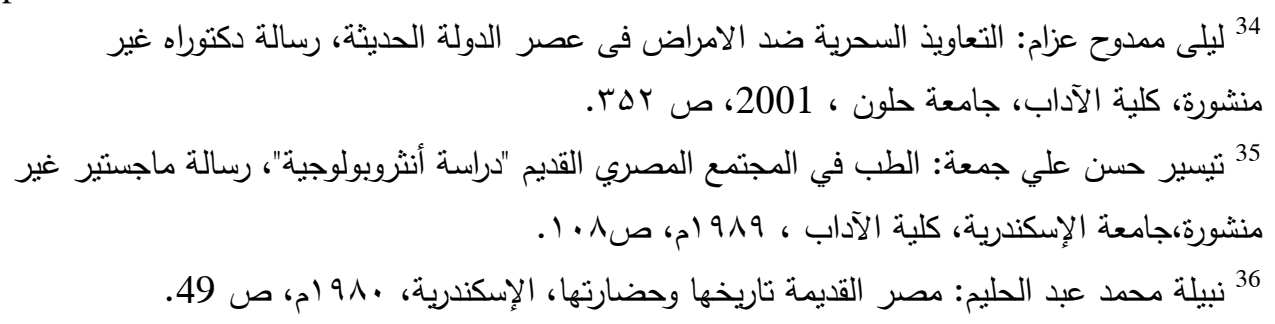


the holder of the title "recited priest" wt inpw back to the era of the second family and the main job of a reciter is to read magic religious and funerary hymns in temples and tombs they were often depicted carrying a roll of papyrus scrolls from which they read religious texts ${ }^{37}$.

The priests of Sekhmet were mentioned in the Edwin Smith and Ebers papyrus with both doctors ( $\breve{s} w n w)$ and witches $(\check{s} 3-W)$ as a medical practitioner and the god Sekhmet, whose name means strong that can cause diseases to punish the guilty ones and the spread of diseases were due to the damages carried by sooty puffs, so the priest in this case can be considered one of the manifestations of the dangerous god, thanks to his purity, the priest can calm his severity, so he can treat the disease ${ }^{.38}$

Whereas the recited priest is the one who recites and memorizes the talismans, as he sometimes composes them, and since he is able to formulate and preserve these talismans, then he is able to eliminate intractable diseases which is due to evil or hidden power represented by the evil spirits and the spirits of the dead which were eliminated by Magic talismans he was also attending the embalming process and reciting talismans while doing this operation. ${ }^{39}$

The priests were at first intermediaries between the patient and the healing god, knowing the ways of begging to him and the way to attract his consent they were savvy and knowledgeable, as they knew plants and used them to enhance their talismans and they had a great knowledge of chemistry. ${ }^{40}$

Also, some of them have practiced harmful magic as they use magic to harm someone by shedding disease on him and it was stated in paragraph no. (8550) of the Ebers Papyrus that a recited priest could have infected a person by practicing what is called black or harmful magic, and about sabotaging the heart and forgetting the mind: it denied his work as a priest. ${ }^{41}$

From the foregoing it becomes apparent that medicine used to be under the responsibility of priests, and they are also responsible for memorized books as the priest used to practice medicine with knowledge and study and enveloped it with magic talismans and psychological words that

$$
\begin{aligned}
& 37 \text { ليلى ممدوح عبد الفتاح عزام:مرجع سبق ذكره، ص345. }
\end{aligned}
$$

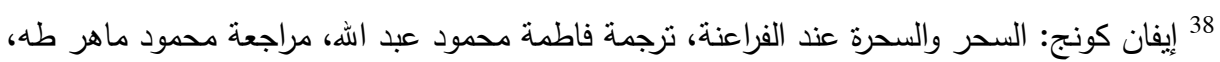

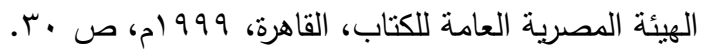

${ }^{39}$ Ghalioungui, P, The Physicians of Pharaonic Egypt, Cairo, 1990, p. 10.

40 محمد بيومي مهران: مصر والثرق الأدنى القديم، الحضارة المصرية القديمة، ج ل، الأسكندرية ،

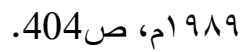

${ }^{41}$ Blackman, W., The Fellahin of Upper Egypt, London, 1927, p. 190. 
affects the patient psychologically with his medical treatment, so the desired effect occurs and healing takes place, which is now known as immunology and since psychological therapy works to raise immunity and fight diseases ${ }^{42}$.

\section{THE THIRD TOPIC: HABITUATION TREATMENT METHODS AND COMPARISON WITH MODERN TREATMENT}

The symptoms of Habituation were similar to the symptoms of mental illness, so they were described as mental illnesses, because the drug is a natural substance or a product that leads to a state of habituation that harms the health in psychological and social state and this is due to the narcotic substances of various types affect the psychological and mood states of people by affecting the central nervous system, so the narcotic substances enter through the blood circulation and it penetrates the imaginary barrier of the brain, enters into different brain regions (each substance has a different region for which it has a target), and then it goes to the respiratory and cardiac centers, vascular control centers, sensory centers, pleasure and pain centers, internal opioid production areas, memory centers, equilibrium, kinetic coordination of anthropomorphic, regions of body temperature regulation, and areas responsible for hormonal production which leads to severe mental disorders and perceptual disorders, so the addict cannot appreciate time, space and distances and get depressed , anxiety, schizophrenia, paranoia, sleep disturbance, psychosis, fear, sensory disturbance, low ability to concentrate, assimilate and remember, rapid agitation and irritability, poor moving skills, and sharp breathing, atrophy of brain cells that may result in insanity ${ }^{43}$.

From the aforementioned symptoms of Habituation and what leads to it, the ancient Egyptians clearly described them as cases of abuse that leads to insanity, so it was necessary to work on treating them and they diagnosed, described their conditions and put the appropriate treatment for them to treat this case, the patient was taking treatment in the temples which nowadays is the role of Habituation treatment clinics also during the period of the patient's presence in these temples and practiced some treatments with curative music and the treatment with writing letters to the dead.

42 James F., Ancient Egyptian Medicine, Glasgow, 1983, p. 7.

$$
\begin{aligned}
& 43 \text { نادية جمال الدين زكي : الآثار الصحية لتعاطي وادمان المخدرات بين الحقيقة و الوهم ، المجلس } \\
& \text { القومي لمكافحة ـ و علاج الإدمان ، القاهرة ، دون طبعة ، } 2005 \text { ، ص } 49 .
\end{aligned}
$$




\section{THE ROLE OF THE TEMPLE IN TREATMENT}

Faith healing is considered the oldest method for spiritual healing of diseases, as it dates back to the era of primitive man in his first graduation towards civilization, as it was a mix between a religion talismans and a mysterious magic, and some primitive peoples still today link religious healing with religious or magical reasons, and those who practice it are still clergy or magicians and that is through several forms of magic talismans to expel the pathogenic spirits, especially neurological and psychological diseases $^{44}$.

The ancient Egyptians used to go and take refuge in the temples of their gods. In addition to being places of worship, they were the main temples of treatment in the capitals and they were visited by many people and pilgrims, demanded recovery from the far reaches of the country in pursuit of what their generous gods loved them by taking care of them and healing them ${ }^{45}$.

Patients used to go to doctors for treatment of their ailments the temples attracted the masses of worshipers because of the popular remedial homes they contain, and the social pleas that pilgrims receive during religious ceremonies $^{46}$.

Such spiritual and magical effects had a great effect in healing the diseases that required psychological or spiritual treatment in ancient Egypt. Therefore, it was one of the most successful ways to expel the malignant spirits is to put the patient's body under the protection of the gods, even if the body suffered, the gods suffered with it. Based on this, the recourse to the gods with the recitation of religious texts was a kind of psychological suggestion intended to concern the patient and his treatment. The ancient Egyptians if they were infected by a severe disease, they went to worship, sacrifice, incense, and sophistication, which is what is recently called "psychiatric or spiritual medicine ${ }^{47}$."

\section{HOLY SLEEP}

Healing from diseases was one of the most important things that meant therapeutic and curative sleep which is called the term nursery sleep

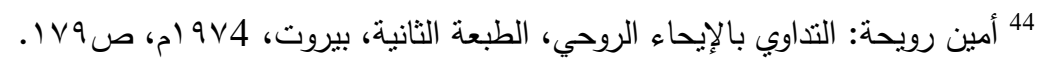

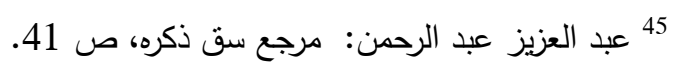

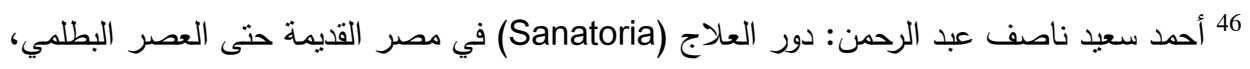

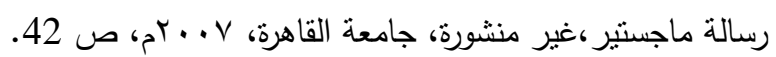

$$
\begin{aligned}
& 47 \text { سمير يحيى الجمال: ناريخ الطب والصيدلة المصرية، ج1، الهيئة المصرية العامة للكتاب، القاهرة، }
\end{aligned}
$$

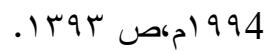


(incubation). Which means spending the night in a temple or in a holy place in the hope of seeing God in a dream for healing or consulting him in times of crisis. ${ }^{48}$

There are documents referring to the "incubation" method in the temple as a way to obtain healing, there is a story written in demotic that tells us that the high priest of "Ptah" in the city of Memphis "Santi - Khamwas" His wife, "Mah - oskht" went to the temple "Imhotep" in Memphis to invite him, she fell asleep at the temple and took medication from the god in a dream. When Santi went to sleep, he saw in the dream that his wife was pregnant and would name the child "Seiya-Uzir".

Also, it was found a plaque from Memphis dating back to the era of Ptolemy XIII concerning the High Priest of the god Ptah called "Ba-ShriAn Ptah" this painting reveals: His wife, the hereditary princess, TaiImhotep, was pregnant three times but gave birth only to girls, and the priest begged God Imohotep, ${ }^{49}$ who listened to his complaint and came in a dream, told him to do a great job in Memphis, and I will give you a child ${ }^{50}$. Sleeping in the temples or holy places happened to get treated from different diseases and it was an inspiration from the god during sleeping and it was already achieved in cases of awakening and the emotional or suggestive the patient became better because the possibility of his recovery and even in the hopeless illnesses, the patient feels a great deal of relief when he comes to the Deity temple and attains his blessing ${ }^{51}$.

The ancient Egyptians sought to practice this habit, requesting to see God in a dream for many purposes, perhaps the most important of which was to seek divine healing from diseases in sick cases, especially mental illnesses such as touch, insanity, movement patterns, and lack of control over speech.

Therapeutic sleep or holy sleep was carried out in the temples in order to recover from many diseases and the god suggests to the patient visions during normal sleep or fall under the influence of drugs and then the priests will interpret these dreams. In the event that the patient did not sleep, the priest would present himself as a mouthpiece of the deity and prescribe to him the treatment that would guarantee his recovery, and there is no doubt that healing in many cases was coming to the expectation of the patient himself that healing was inevitably coming to him, and after recovery, many thankful believers were bound by the temple while they were in a

${ }^{48}$ Daumas, F., "La Sanatorium de Dendara" BIFAO, vol,56 (1957), p. 50.

$$
\begin{aligned}
& 49 \text { هاري، ج: أمحتب إله الطب والهندسة، ترجمة محمد العزب موسى، مراجعة محمود طه،مطبعة هيئة }
\end{aligned}
$$

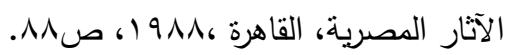

$$
\begin{aligned}
& 50 \text { أحمد سعيد ناصف عبد الرحمن: مرجع سبق ذكره، ص43ة الرهة، }
\end{aligned}
$$

${ }^{51}$ Op. Cit p44. 
state of great joy and happiness, Their effect affects newcomers and makes them more willing to accept the inspiration.

And the gods that the Egyptians took refuge to seek hospitalization or help with something in the nursery sleep, they are predominantly the popular gods of the Egyptians such as: the goddess Iza and the god Bas, in addition to qualified humans like Imhotep and Amenhotep bin Habu. ${ }^{52}$

Sleeping places have been designated adjacent to the temples of these gods, which were a destination for people who come to spend the night in them, hoping to have a dream from God to help them recover from their ailments. Thus, these places were more like a hospital for treatment of diseases which mentioned in the era of the modern state, the area of Deir el-Medina, where the goddess "passed through a sacred" that became famous and spread there as one of the popular gods that people went to seek hospitalization ${ }^{53}$.

\section{MASSAGE THERAPY AND REFLEXOLOGY}

But what is reflection or reflexive thinking the word "reflexology" is derived from the word reflex, that is, a reflexology procedure, and the reflexology is completely similar to acupressure, which in turn is derived from the word (acupuncture), which is the Chinese medicine known as acupuncture. In our world today, there are many difficulties in our homes, in our work, in our surroundings, even in the quality of our food and the medicinal drugs rely on most of what is needed. These difficulties, the causes of psychiatric disorder, and anxiety are often the factors behind many diseases, and reflexology is one of the natural medicine that helps us get rid of the causes of psychiatric disorder and anxiety ${ }^{54}$.

This science relies on activating the points of the reflex reaction in the feet or hands, By pressing directly on the glands, nerves and other parts of the body, which in turn facilitates better circulation of blood and vital energy, Therefore, one of its most important effects is the elimination of muscular and psychological tensions that negatively affect public and psychological health ${ }^{55}$.

Reflexology is based on a philosophy that relies on reflection points connected to energy pathways that transcend all internal and external parts of the body in the palms and feet. And when you press those points

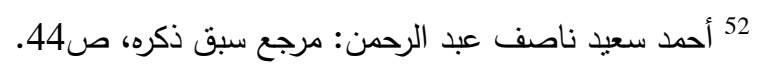

${ }^{53}$ Wildung, D., "Heilschlaf', LA, II,(1977), Col. 1101. (3) Pinch, G., op. cit., p. 164.

$$
54 \text { سامية حمزة عزام: الدليل الصحي للعلاج بالريفكسولوجي، دار الآفاق الجديدة، بيروت، لو99 م، }
$$

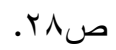

${ }^{55}$ Kunz,B.,\&Kunz,K., Medical Application of Reflexology, USA, 1995, p. 30. 
steadily with the tips of the fingers, the energy moves, this leads to the activation of the body's organs, removal of soreness, and restoration of the body's balance by stimulating the circulatory system and lymph nodes, and the body gets rid of toxic substances. It also makes the body more adapted to the stresses of daily nerve life that each of us meets, regardless of their source, practical, romantic, physical, or environmental. This science helps in the treatment of some of the existing diseases such as back pain, constipation, increased blood pressure, irritable bowel syndrome, migraines, difficulty sleeping, tension and unstable circulation ${ }^{56}$.

The ancient Egyptians are among the first people to use massage and reflexology as a treatment also, they were the first to know essential oils and studied their therapeutic benefits and their effect on the human mood as well as the installation of beautiful perfumes and fragrant incense for personal use or in religious rituals, Then they began to develop this knowledge as they used it in massage and reflexology to become one of the alternative treatment methods or alternative medicine to treat many diseases, and the goddess Eza is famous for using the therapeutic massage to treat several diseases ${ }^{57}$.

As for massage, it is the science or art of applying pressure with hands, or performing measured movements by hands, or tools that have vibrations on body tissues, including the muscles, ligaments, and joints. It can be practiced on one part of the body or the entire body to treat injuries relieves psychological pressure and improves blood circulation ${ }^{58}$.

The ancient Egyptians relied on treatment on surgery, drugs, ointments, and massages with various types of oils. The ancient Egyptians used many methods to massage their bodies using either hands only, or after painting the body with some medicinal and aromatherapy oils(fig no 9$)^{59}$.

The ancient Egyptians considered the first to use massage and as reflexology as an alternative treatment and body care. The ancient Egyptian was aware of the beneficial effects of massage on the body, including relieving pain and relaxation, The massage was used to relax, beautify and care for the skin while reflexology is used mostly for medical purposes, and some believe that this science originated in ancient Egypt and China thousands of years ago ${ }^{60}$.

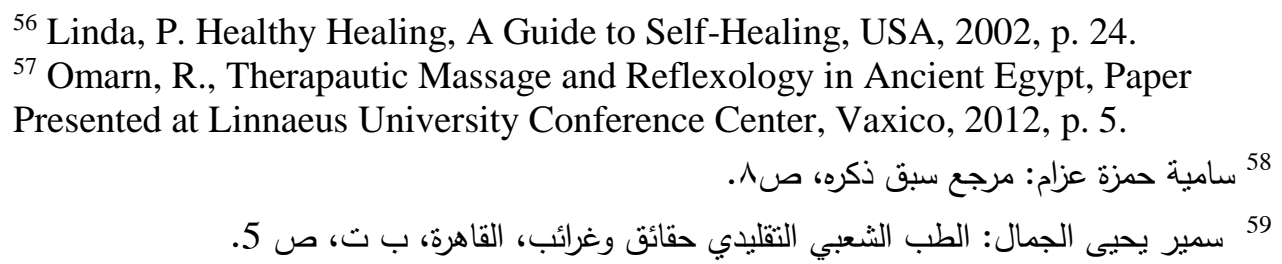

${ }^{60}$ Linda, F., op. cit., p. 24. 


\section{SENDING LETTERS TO THE DEAD TO SEEK RECOVERY}

The letters of the dead are a set of letters that the living sent to their relatives or acquaintances of the dead in order to seek help in problems related to inheritance or treatment of some diseases or the settlement of family disputes, or having a healthy baby, or asking to stand with the living against the evil spirits or troublemaker of the sender, whether alive or dead, this is in addition to the request for mediation in the other world, and the history of these speeches dates back to the period between the era of the Old Kingdom and the era of the third transition ${ }^{61}$.

The ancient Egyptians have shown from the early ages the desire to contact the inhabitants of the other world, as evidenced by the letters of the dead, from which it is evident from the ancient Egyptian belief in the ability of the living to contact the dead to seek help from them.

The writers of the ancient Egyptians had their dead writers on the papyrus, and their writers on the vows utensils dedicated the papyrus to long messages and allocated pots for short messages. The letters of the dead were realistic, one of which came: Our people will not know a way to get the food, so why not use this occasion to display the offerings and offer them People believed in the ability of the souls to move and believed in the ability of the dead and their influence. They said that they are capable of good and evil. If the living ones are unable to do something easy for the dead, then they asked the dead to help the difficulties of the world ${ }^{62}$.

These speeches spread widely during the first transitional era, in which the state suffered from confusion, recklessness and feudalism, which led the ancient Egyptian to seek the help of his dead and their lives in the hope of achieving the desired help and aid, a solution to his problems and the healing of his diseases ${ }^{63}$.

The letters were placed close to the body at the time of the funeral or when another burial cemetery was reopened, or letters such as Liden's letter 1371were wrapped and bound in a small wooden statue in the cemetery, or crockery placed within the funeral furniture of the deceased ${ }^{64}$.

The topics of these letters and the purpose for which they were sent varied, and what concerns us here is that of seeking recovery from incurable diseases (be it Neurological or psychological). Which doctors are unable ${ }^{65}$ to heal or cure and also ask to stand with the living against the evil spirits that cause trouble to the sender

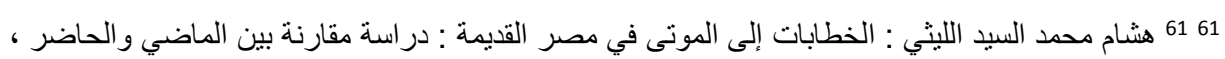

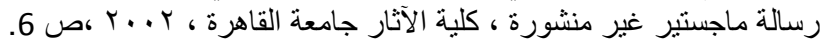

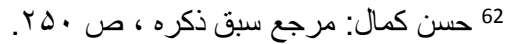

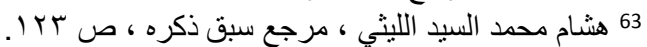
64 Pinch , G., Magic in Ancient Egypt, London, 1994 ,p.150. 65 هشام محمد السيد الليثي: مرجع سبق ذكره ، ص.م • ....
} 
The most important letter whose owner demands recovery from his illness is Nage Eldeear Letter N3500, which included the following phrase: "Heal your children (your children)" and in another letter on the Berlin vase "If these pains were done by you, then know - look - the house with your children is in apparent misery", and in another speech on the Cairo vessel, as for the maid "Emho", who is sick, not to defend her day and night against any evil or wicked man or woman) who works against her As for the Papyrus Letter Leiden 1371: To the smart soul, Ankh Erie, what have I done to you from evil? To be in such a bad situation as I am, what have I done to you?? It is clear that the author of this speech has suffered a psychological condition.

It is clear to us from the above that sending letters to the dead was one of the methods of treatment used by the ancient Egyptian to seek recovery among the psychological or neurological diseases, which were thought to be the cause of evil spirits or demons and in view of the ancient Egyptian conviction of the superpowers possessed by the dead, so he resorted to blessing them and asking for help from them.

Perhaps this method is more akin to Habituation treatment in psychiatry, where the doctor asks the patient to write what is in me to know his psychological condition in order to be able to determine the appropriate treatment the psychological state of the patient appears through the feelings he writes, as well as the method of writing and the patient's handwriting. All these data work to determine the patient's condition and also determine the appropriate treatment method for the patient

\section{MUSIC THERAPY AND PSYCHOLOGICAL SPORTS}

Some types of music help relieve the sadness that afflict a person, and may eliminate them and raise their morale. the researchers mentioned that dancing and singing the rhythm of wood or leather drums or blowing in the copper or wind instruments of primitive man is beneficial for treating the human body's touch with evil spirits or elves and it caused him hidden diseases and did not find them a danger or a cure, and often this dance and singing to the tune of music pushed the patient to enter into a state of delirium, swaying and lack of sensibility, after which he was thrown on the ground unconscious Then he wakes up, and this is the origin of ( al zaar ) in Egypt and some African countries, which is still practiced until now ${ }^{66}$. The ancient Egyptians believed in the impact of music by refining feelings and upgrading feelings, and it is likely that the Coptic Church still preserves some of the tune of our ancestors.

$$
66 \text { أحمد عكاثة: الطريق إلى السعادة، الكرمة للنشر والتوزيع، القاهرة، ـ ا ـ بم، ص15. }
$$


In the ruins of the city of Memphis, the remains of a wall of a small temple attached to the Temple of God Ra, which was dated to the Sixth Dynasty ((BC2280), were found. this wall has inscriptions showing that this temple was intended to treat patients who were suffering from many mental illnesses and that is by treating them with calming music with the use of some calming herbs for nerves, and the priests also used music as a treatment for diseases in Abydos Temple in Upper Egypt And he was considered one of the largest medical treatment centers in all antiquity, as he used toned hymns to treat some neurological and psychological diseases, so the ancient Egyptians were the first to put his hand on the first impulses psychological analysis, as humanity knew it as a stand-alone science in the first half of the ninth century Ten $\mathrm{AD}^{67}$.

And because music is a natural human desire for a person to express himself, his feelings and feelings since he became aware of being able to perceive what was around him and the sense of himself and his being on the ground among other creatures interacting with those around him as an influential living being - music was a means of achieving communication and understanding between a person and those around him in a way that words and signs cannot achieve, however eloquent and accurate ${ }^{68}$.

The temple of "Abydos" in Upper Egypt was famous for being a resort for medical treatment and hospitalization, whereby priests treated those who sought healing by performing prayers on the tune of music from tambourines, sajas, argyll, nay, and others to satisfy the gods. So, it heals the tone of healing on the patient, and therefore a musical band was devoted to the temple and its hospital, which is composed of priests and priests, who chant and sing in addition to some dancers who were swaying to the tones of music and the patients emulated them in their movements, according to their ability ${ }^{69}$. Whereas, sick patients were playing music alongside their family, each according to the type of illness and with special tunes The Jews transmitted many of Akhenaten's religious chants, especially in the psalms of the Prophet David they were reciting, so they perform miracles and relieve the suffering of the sick.

The Egyptians made their idol a musician god and he has a music band of the most skilled female singers. They also made the god Hor son of the god Ozir only for harmony and order and as a director of music and the

$$
\begin{aligned}
& 67 \text { عزة أحمد محمد سلامة: تأصيل مفهوم الطب البديل في مصر القديمة، رسالة ماجستير غير منشورة، }
\end{aligned}
$$

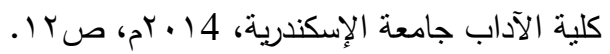

$$
\begin{aligned}
& 68 \text { عبد الحليم نور الدين: الموسيقى في مصر القديمة، الموسم الثقافي الأثري الأول بمدينة الأسكندرية } \\
& \text { الأسكندرية ،ب.ت ص } 5 .
\end{aligned}
$$

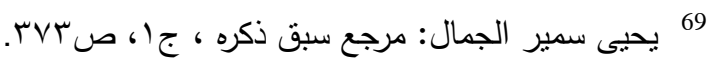


supervisor of the instruments and thus linked their greatest gods and music ${ }^{70}$. This is evidence of their love, reverence for this art, which helped the music advance greatly as an art, science, industry, lifestyle and to heal diseases. Harmonized voice was used as a cure for mental illnesses and the tendons and rhythms were ringing beside the patients ${ }^{71}$.

In the modern era, many experiments have been conducted in many research centers in the countries of the world to demonstrate the effect of music in treating some diseases. Quiet music used treatment for some neurological diseases such as hysteria and nervous irritation it also lowered high blood pressure, and improved heart performance, especially in the case of angina, as well as helped to bring sleepy and sleepy patients with insomnia while fast and loud music used low blood pressure treatment and psychological depression.

As for psychological sport, the Far East has known a kind of spiritual sport, which is considered as advanced treatment methods, including $\operatorname{yoga}^{72}$.

It was known to the ancient Egyptians, who practiced it in their religious rituals, in addition to deep meditation India and China have been famous for this type of medicine. It was found in the tombs of Bani Hassan what depicts a boy who depends on the corner of his head and maintains his balance in complete integrity without being focused on his hands or hands and these movements may be one of the movements of yoga.

Sports of spirit and soul revealed to the ancient Egyptians that yoga was known to them and they had a head start in practicing it, and that it was in religious rituals, many pictures were found to yoga poses in the graves of the fossils of the ancient state, which were researched by the French scholars, "Sanyos" and "Whopper", which proved that the priests of the Pharaohs were the first to lay the foundations of yoga and that they practiced it within their sacred rites starting from the first family, Professor Al-Weberi also revealed that "the first position of yoga is to raise the arms up to receive the cosmic forces expressed by the ancient Egyptians with the sign of" Alka ", meaning the soul that they depicted in the form of two arms extended to the top pointing to the sky $^{73}$. Dancing scenes were known in ancient Egypt since the "Naqawa" civilization, before the era of the families, where drawings and statues of men and women dancing were found. Dancing to the music of Nay and drums soon penetrated the lives of

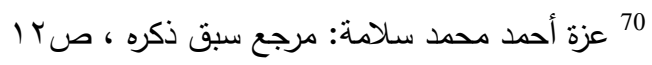

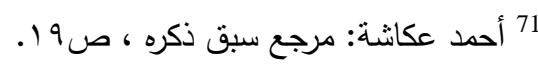

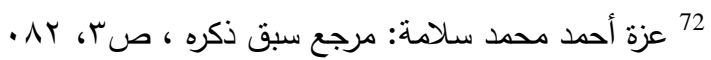

${ }^{73}$ Cummings, J., Temple Dance in Ancient Egypt, PH.D, New York University 2000 , p. 88. 
the Egyptians throughout their ancient history and knew many shapes and patterns from them thanks to the patronage of religion, which was one of the important pillars and characteristics of its rituals. It is performed by women and men as well as by kings ${ }^{74}$.

\section{THE CONCLUSION}

Habituation is one of the oldest phenomena in the ancient Egyptian civilization that means habituation and popularity of something, as the ancient Egyptians were used to drink wine, bear and having poppy plant. They knew wine and called it (irp), besides drinking bear. Wine was the drink of rich people, as it was the most important kind of alcohols in ancient Egypt.

Many scenes of drinking beer and other intoxicating substances in the graves and temples and also the great numbers of wine and beer pots that were found in fossils shows the Egyptians' fondness to drink alcohol especially during holidays, celebrations and feasts.

The ancient Egyptians knew the poppy plant and used it in the medical papyri and in the direct handling. They presented its flower to the princes and kings as a gift. Also the poppy plant was mentioned in the ancient Egyptian literature.

The symptoms of habituation were similar to those of psychological diseases, as it was described as one of the psychological diseases because the psychotic is a natural substance or a product leads to a state of habituation and all kinds of narcotic substances affects the health, psychological, and social status of the individual and also his mood.

The persist and magicians in ancient Egypt played the role of doctors in diagnosing the habituation state as a hysteria case lead to madness and must be treated. They diagnosed described, evaluated, and put the suitable therapies of such cases. So handling treatment was in the temples and it is the role of addiction clinics nowadays. During the treatment period in those temples the physicians used music and writing letters to dead in treatment.

Some of the previous methods of treatment is used now in treating addiction such as writing the patient feeling to take out what's inside. The ancient Egyptians used the same methods like writing letters to the deeds and showing the inner feelings, and also using music in treatment as nowadays.

Attached to the research a table of ancient Egyptians key words on intoxicating and narcotic substances that causes habituation.

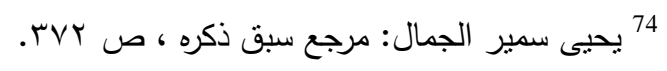


Figures

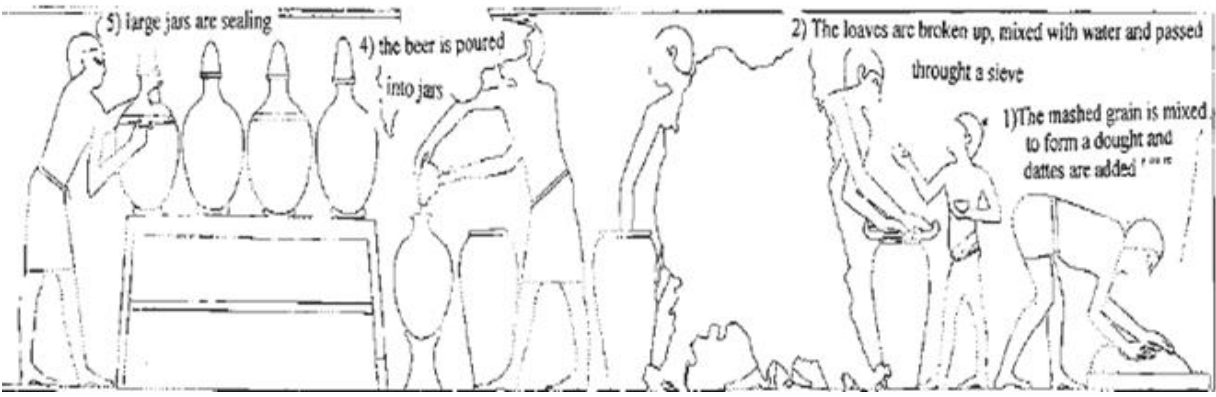

Figure1: Process of brewing, Theban Tomb of Intef-iker, D. XII. (Kemp, B., Elantiguo Egipto, p. 155).

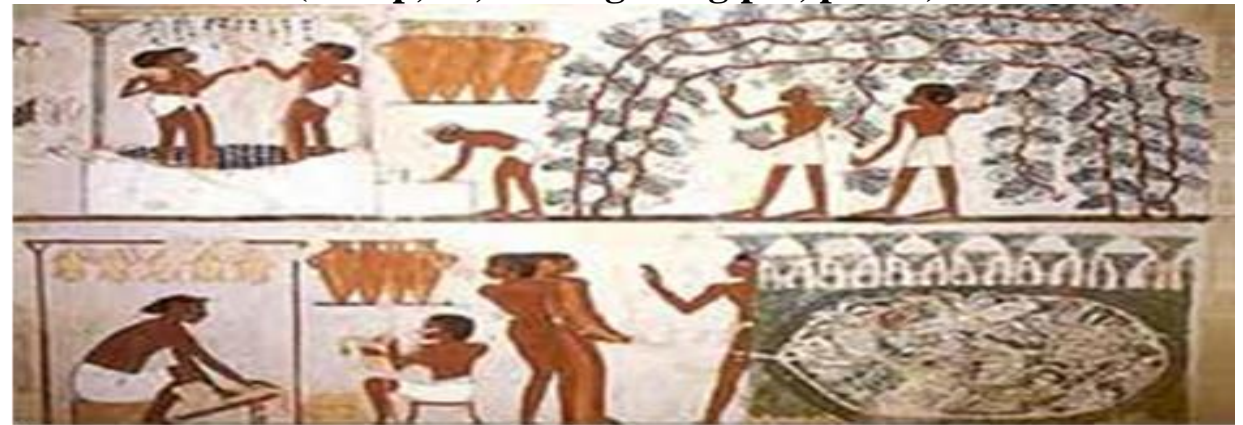

Figure 2: Egyptian tomb paintings depicting grape cultivation, Tomb of Nakht`(Theban Tomb 52) D. XVIII, c.1400 B. C., now in British Museum.

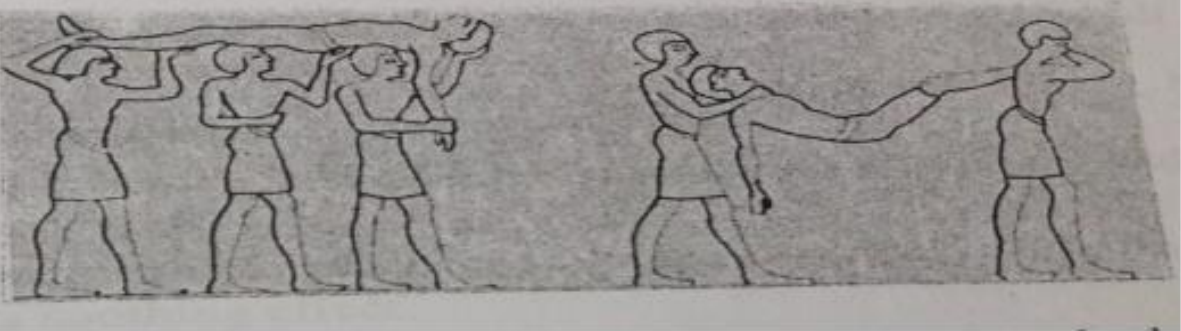

Figure 3:Egyptian Medicine in the days of the Phoraohs, Cairo,1999,

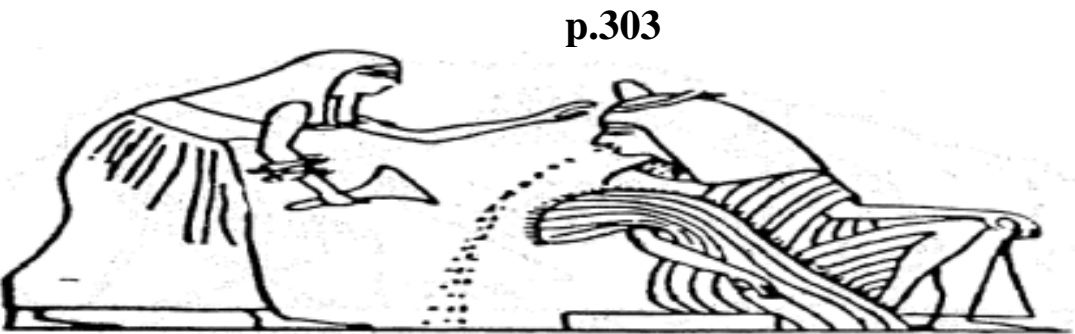

Fig 4 : woman sitting cross-legged in severe vomiting Ebeid, N.,opcit,p.302 


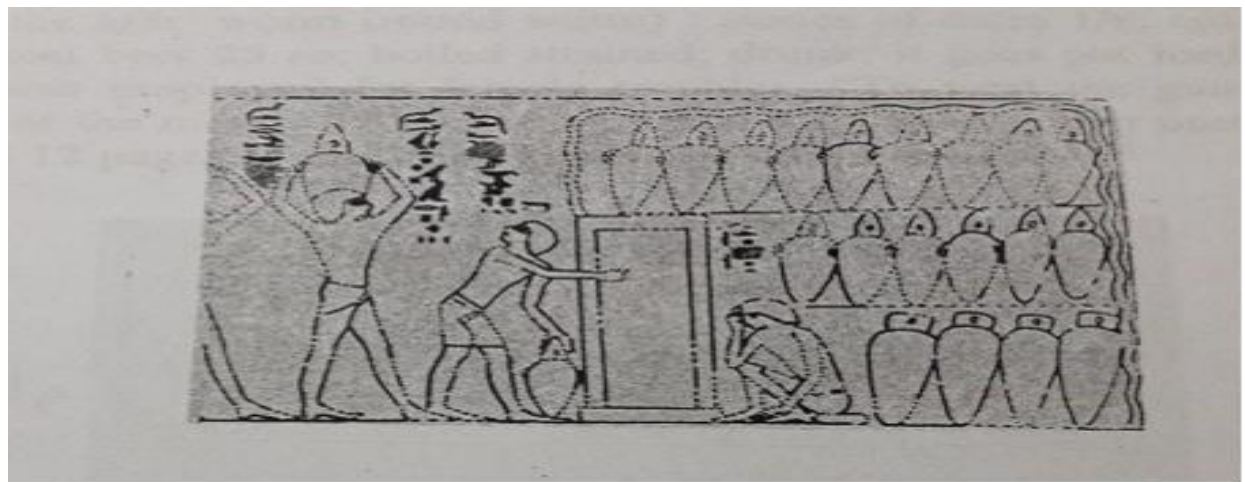

Figure 5: flying fumes from the puppies Ebeid, N.,opcit,p.303

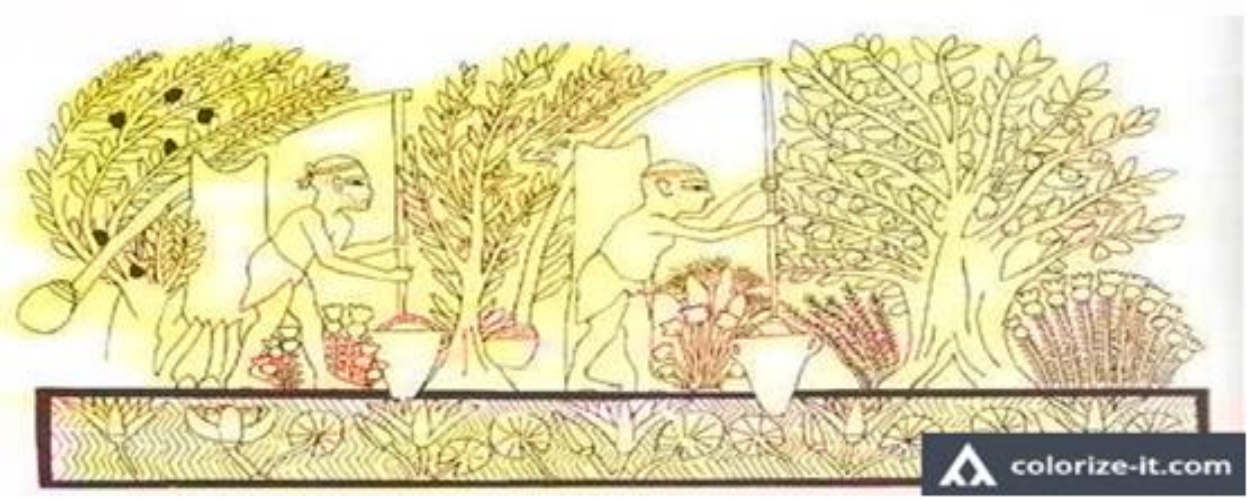

Figure 6: Gardeners among persea, sycamore fig, cornflowers, mandrake and poppies. In the pond are blue and white lotus flow-ers. Wall-painting in a Theban Tomb Ramesside 217. (Manniche L. An Ancient Egyptian Herbal: p. 12

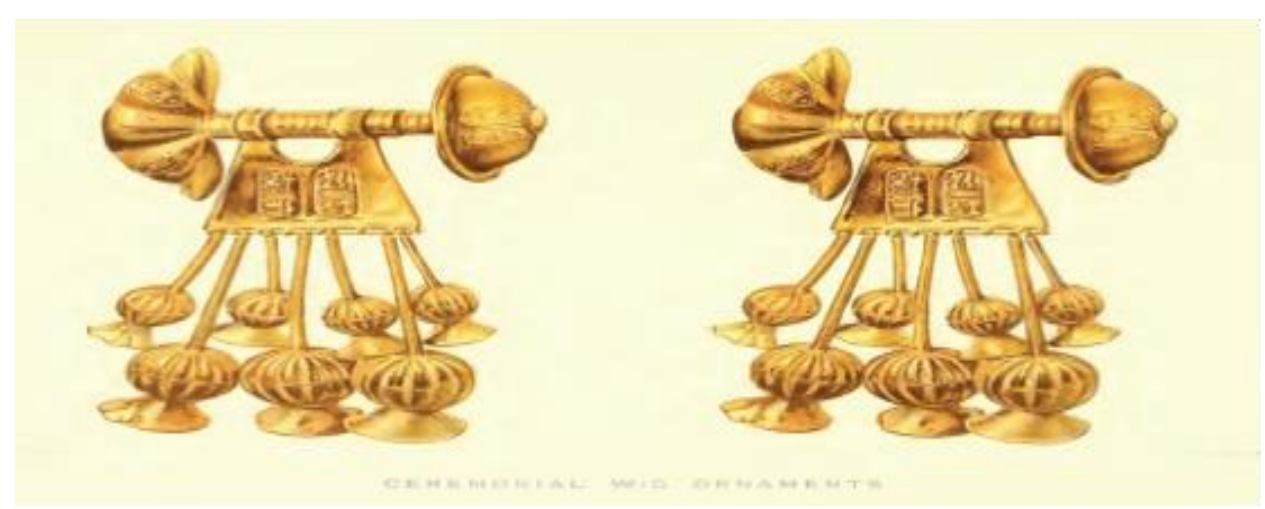

Figure 7 : Queen Tawseret's earrings

Davis, 1908: plate VII 

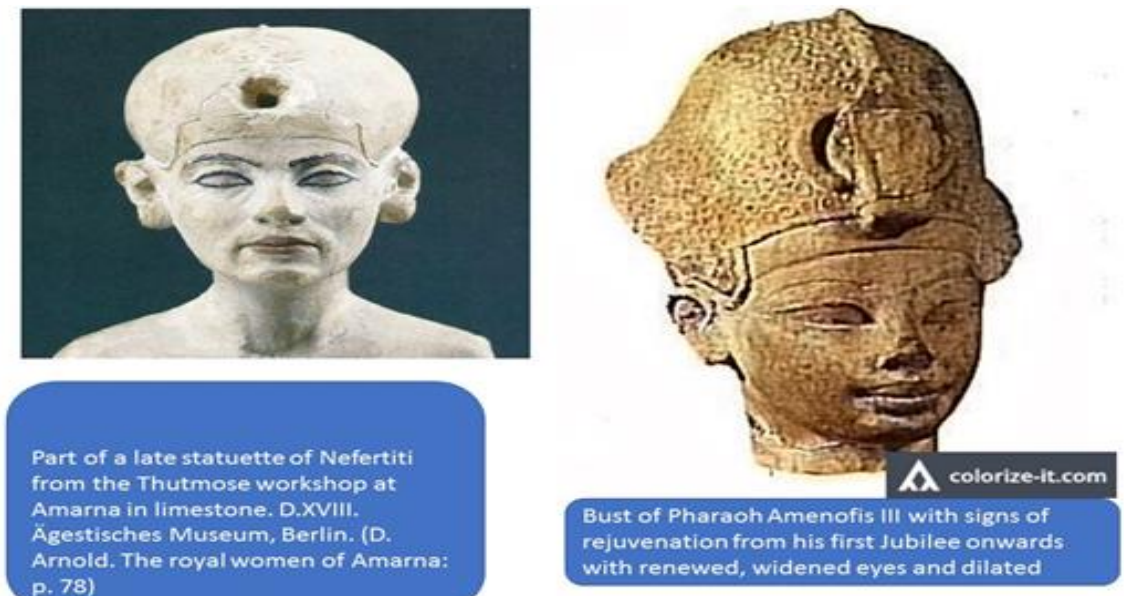

Part of a late statuette of Nefertiti

from the Thutmose workshop at

Amarna in limestone. D.XVIII.

Ägestisches Museum, Berlin. (D.

Arnold. The royal women of Amarna:

p. 78 )

with renewed

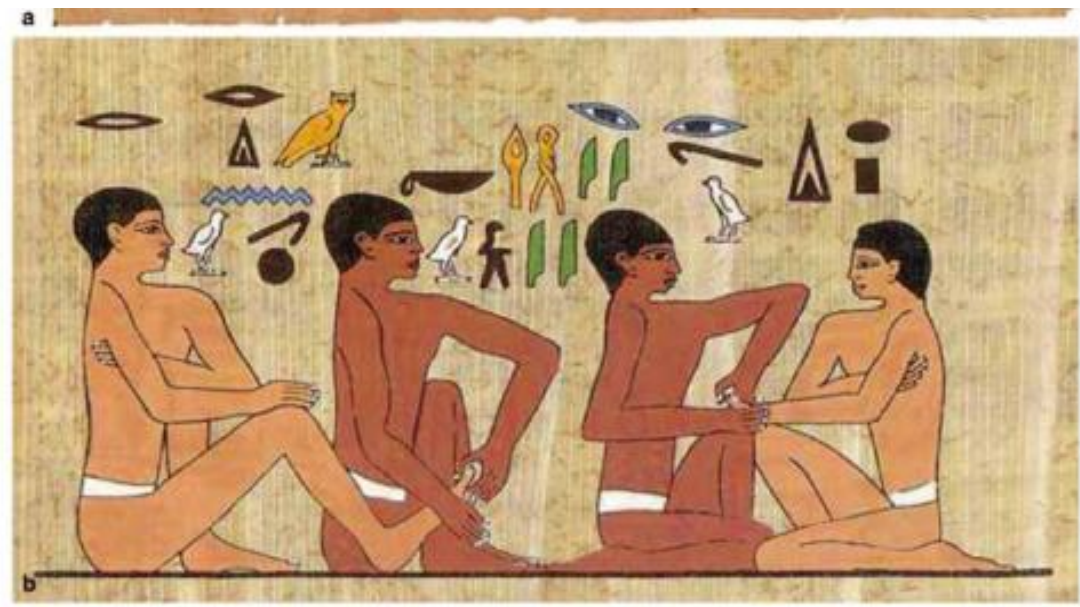

Figure 9 : The ancient Egyptian massage

http://www.icve.net/reflexology.htm

\section{REFERENCES}

- Blackman, W., The Fellahin of Upper Egypt, London, 1927.

- Cummings, J., Temple Dance in Ancient Egypt, PH.D, New York University 2000.

- $\quad$ Daumas, F., "La Sanatorium de Dendara" BIFAO, vol,56 1957.

- Ebeid ,N., Egyptian Medicine in the days of the Phoraohs, Cairo, 1999.

- Faulkner, FCD, p. 28.

- Ghalioungui, P, The Physicians of Pharaonic Egypt, Cairo, 1990.

- Ghalloungui, P, Magic and Medical Science in Ancient Egypt, London, 1963. 
- H. Kama 1, Dictionary of Pharaonic Medicine, Cairo, The National Publication House, 1967.

- Hussein, M., Mental Health and Psychological Medicine at the time of Pharaohs M.Sc‘.Cairo, 1993.

- James F., Ancient Egyptian Medicine, Glasgow, 1983.

- Kunz,B.,\&Kunz,K., Medical Application of Reflexology, USA, 1995.

- Lichtheim, M., Ancient Egyptian Literature, VII..

- Linda, P. Healthy Healing, A Guide to Self-Healing, USA, 2002.

- Lutz, H., Viticulture and Brewing in the Ancient Orient, Leipzig, 1992.

- Omarn, R., Therapautic Massage and Reflexology in Ancient Egypt, Paper Presented at Linnaeus University Conference Center, Vaxico, 2012.

- $\quad$ Pinch, G., Magic in Ancient Egypt, London, 1994.

- Rinter,K., The Mechanics of Ancient Egypt Magical Practice,, Chicago, 1993.

- Wb. IV,444.

- Wildung, D., "Heilschlaf',LA, II, 1977.

\section{قائمة المراجع العربية}

• أحمد سعيد ناصف عبد الرحمن: دور العلاج (Sanatoria) في مصر القديمة حتى العصر

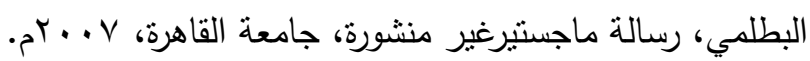

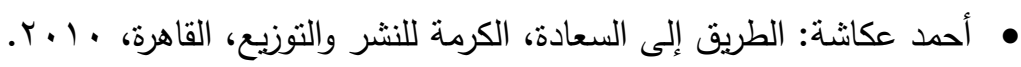

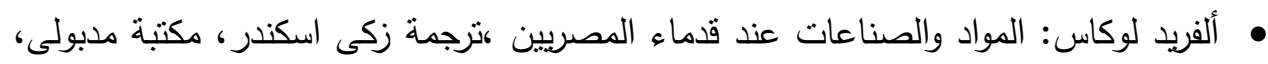
القاهرة . • أمين رويحة: النداوي بالإيحاء الروحي، الطبعة الثانية، بيروت، 9 ام ام.

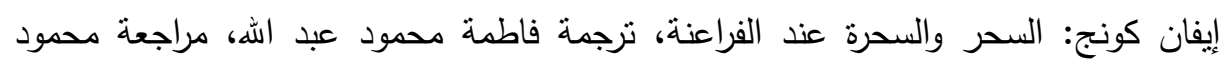
ماهر طه، الهيئة المصرية العامة للكتاب، القاهرة، 999 ام. 99

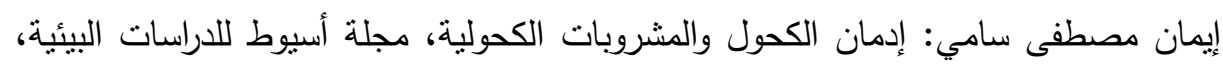

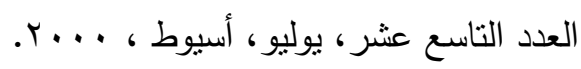

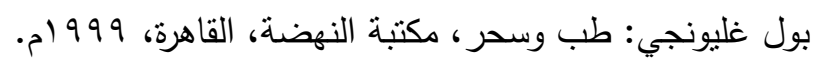

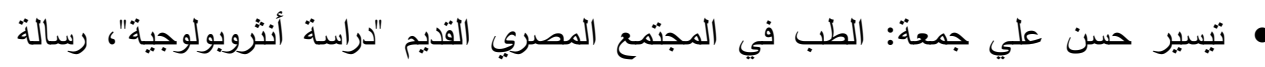

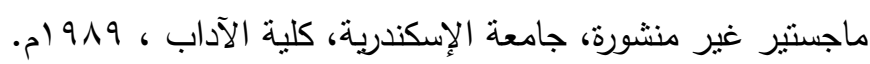

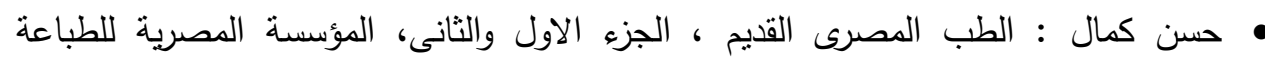

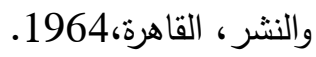


• حسن كمال: الطب المصري القديم، الهيئة العامة للكتاب، القاهرة، 991 1. • سامية حمزة عزام: الدليل الصحي للعلاج بالريفلكسولوجي، دار الآفاق الجديدة، بيروت، . $) 99 \mathrm{~V}$

همير يحيى الجمال: الطب الشعبي التقلبدي حقائق وغرائب، القاهرة. همير يحيى الجمال: تاريخ الطب والصيدلة المصرية، ج1، الهيئة المصرية العامة للكتاب،

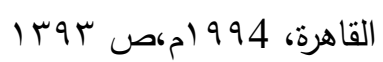
عبد الحليم نور الدين: السحر والسحرة في مصر القديمة، الموسم الثقافي الأثري السابع بمكتبة الإسكندرية. • عبد الحليم نور الدين: الطعام والثراب في مصر القديمة، الموسم الثقافي الأثري السابع، مكتبة الإسكندرية. عبد الحليم نور الدين: الموسيقى في مصر القديمة، الموسم الثقافي الأثري الأول بمدينة الأسكندرية ،الأسكندرية. عزة أحمد محمد سلامة: تأصيل مفهوم الطب البديل في مصر القديمة، رسالة ماجستير غير

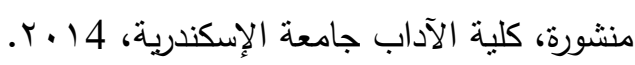
كلير لالويت:نصوص مقدسة ونصوص دنيوية من مصر القديمة ، ترجمة: ماهر جويجانى، المجلد الثانى، دار الفكر للاراسات والنشر ، القاهرة، 199. ليلى ممدوح عزام: التعاويذ السحرية ضد الامراض فى عصر الدولة الحديثة، رسالة دكتوراه غير منشورة، كلية الآداب، جامعة حلون ، 2001.

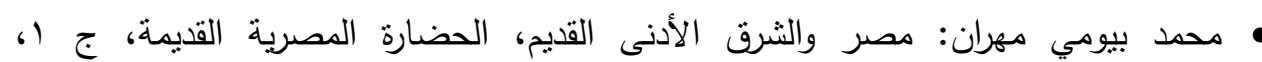

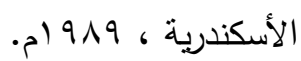
• مها سمير عبد السلام القناوي: زراعة الكروم وصناعة النبيذ في مصر القديمة، رسالة ماجسنتير غير منشورة، جامعة القاهرة، 911 (م. نادية جمال الدين زكي : الآثار الصحية لتعاطي وادمان المخدرات بين الحقيقة و الوهم ، المجلس القومي لمكافحة . و علاج الإدمان ، القاهرة ، دون طبعة ، 2005. نادية جمال: تطور ظاهرة المخدرات في مصر، المؤتمر السنوي الخامس، ، المركز القومي للبحوث الاجتماعية والجنائية، القاهرة 4 ـ. ب بم. •بيلة محمد عبد الحليم: مصر القديمة تاريخها وحضارتها، الإسكندرية، ـ91 ام. نحيب متري : آداب قدماء المصريين وديانتهم ، دار المعارف ، القاهرة . 
• هاري، ج: أمحتب إله الطب والهندسة، ترجمة محمد العزب موسى، مراجعة محمود

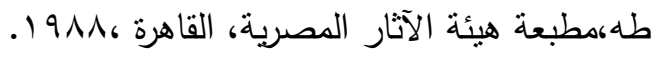

• هشام محمد السيد الليتي : الخطابات إلى الموتى في مصر القديمة : دراسة مقارنة بين الماضي والحاضر ، رسالة ماجستير غير منشورة ، كلية الآثار جامعة القاهرة ، Y . . . . • وليم نظير: الثروة النباتية عند قدماء المصريين، الهيئة المصرية العامة للتأليف والنشر، الثهاء

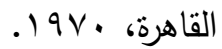

• يوليوس جيار، لويس رينز : الطب والتحنيط في عهد الفراعنة، تعريب أنطوان زكري، مكتبة

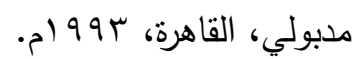

List of words indicating drugs and their derivatives in the ancient Egyptian language

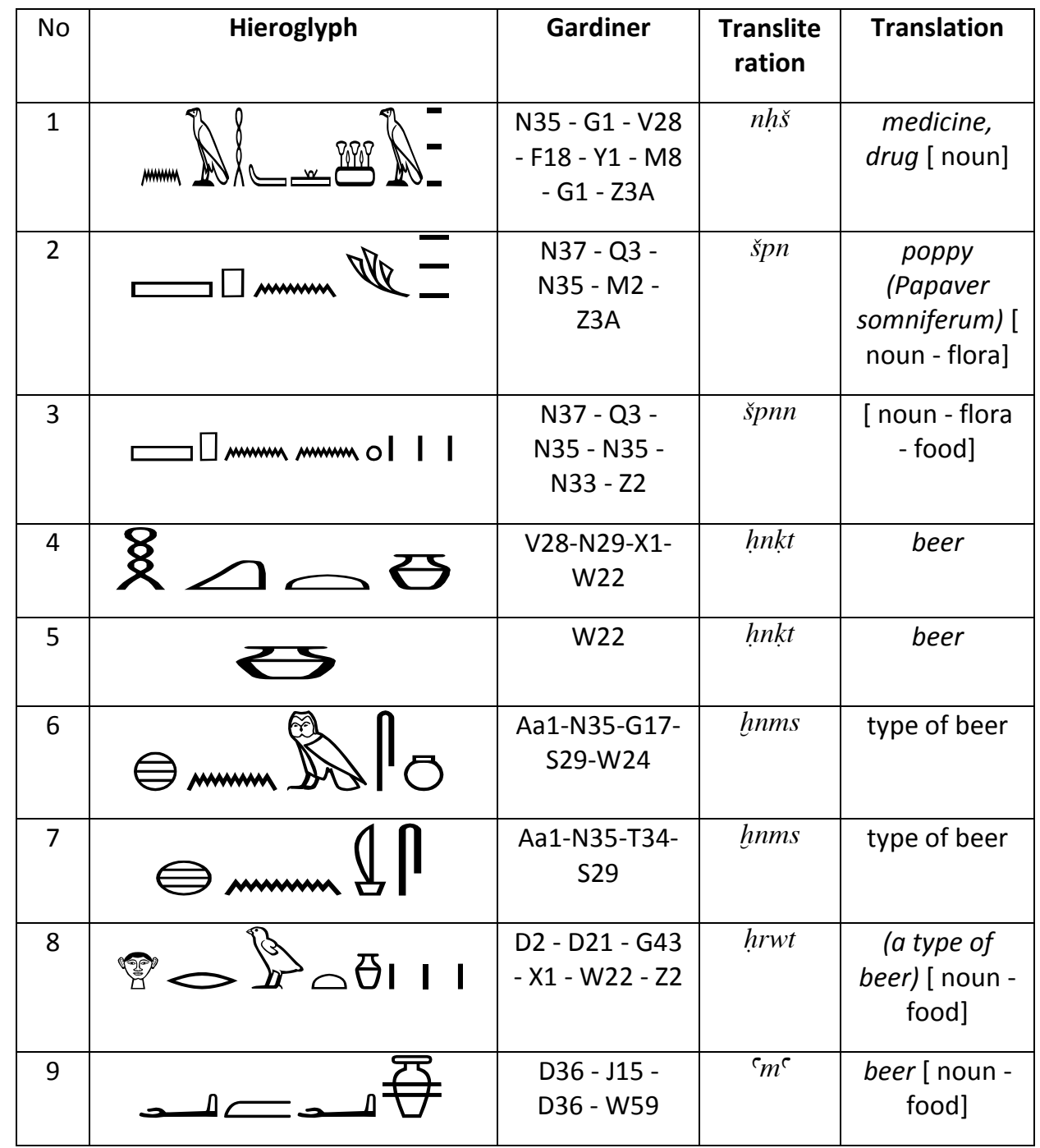




\begin{tabular}{|c|c|c|c|c|}
\hline 10 & $\underset{ }{\bar{\sigma}}$ & $\begin{array}{c}\text { D36 - N37 - } \\
\text { W59 }\end{array}$ & $\dddot{S}$ & $\begin{array}{c}\text { beer jug [ } \\
\text { noun - furn.] }\end{array}$ \\
\hline 11 & & $\begin{array}{l}\text { D36 - N37 - Z5 } \\
- \text { Z5 - Z5 - W23 }\end{array}$ & 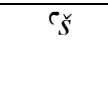 & $\begin{array}{c}\text { beer jug [ } \\
\text { noun - furn.] }\end{array}$ \\
\hline 12 & $=$ & $\begin{array}{l}\text { D46 - W19 - } \\
\text { M17 - W22 }\end{array}$ & $d m i$ & $\begin{array}{l}\text { (beer) pot, } \\
\text { jug [ noun - } \\
\text { furn.] }\end{array}$ \\
\hline 13 & & $\begin{array}{c}\text { D58 - N41 - X1 } \\
- \text { W10 }\end{array}$ & bi3t & $\begin{array}{c}\text { beer } \\
\text { container [ } \\
\text { noun - furn.] }\end{array}$ \\
\hline 14 & n. & $\begin{array}{c}\text { G17 - D36 - } \\
\text { T28 - D21 - Z7 } \\
\text { - N23 }\end{array}$ & $m h r w$ & $\begin{array}{l}\text { dregs, lees (of } \\
\text { beer) [ noun] }\end{array}$ \\
\hline 15 & 成 & $\begin{array}{c}\text { G17 - D36 - } \\
\text { U28 - G1 - } \\
\text { M17 - M17 - } \\
\text { W23 }\end{array}$ & $m \underline{d} 3 y$ & $\begin{array}{l}\text { (beer) jug, jar } \\
\text { [ noun - furn.] }\end{array}$ \\
\hline 16 & 19 & $\begin{array}{l}\text { G20 - I10 - } \\
\text { N29 - U33 - } \\
\text { M17 - W22 }\end{array}$ & $m \underline{d} \underline{d} t$ & $\begin{array}{c}\text { container (for } \\
\text { beer, oil, } \\
\text { honey) [ noun } \\
\text { - furn.] } \\
\text { \{capacity of } \\
38 \text { hin\} }\end{array}$ \\
\hline 17 & $\frac{\rho}{\square \mid}$ & $\begin{array}{c}\mathrm{J} 18 \text { - Z1 - D58 - } \\
\mathrm{G} 41 \text { - G1 - Z4 - } \\
\mathrm{D} 21 \text { - Z1 - M2 } \\
-\mathrm{Z} 2\end{array}$ & $s b r$ & $\begin{array}{c}\text { wine, alcohol } \\
\text { [ noun - food } \\
\text { ] }\end{array}$ \\
\hline 18 & \{ & $\begin{array}{l}\text { M17 - D21 - } \\
\text { Q3 - G43 - } \\
\text { W22 - Z2 }\end{array}$ & irp & $\begin{array}{l}\text { wine [ noun - } \\
\text { food] }\end{array}$ \\
\hline 19 & & $\begin{array}{l}\text { M17 - D21 - } \\
\text { Q3 - M17 - } \\
\text { M17 - X1 }\end{array}$ & irpyt & $\begin{array}{c}\text { wine jug [ } \\
\text { noun - furn.] }\end{array}$ \\
\hline 20 & 夰地 & $\begin{array}{c}\text { M17 - D21 - } \\
\text { Q3 - M43 }\end{array}$ & irp & $\begin{array}{l}\text { wine [ noun - } \\
\text { food] }\end{array}$ \\
\hline 21 & minm & $\begin{array}{l}\text { M17 - D21 - } \\
\text { Q3 - N35A }\end{array}$ & irp & $\begin{array}{l}\text { wine [ noun - } \\
\text { food }\end{array}$ \\
\hline
\end{tabular}


International Journal of Tourism and Hospitality Management Volume 3 Issue 1, June 2020

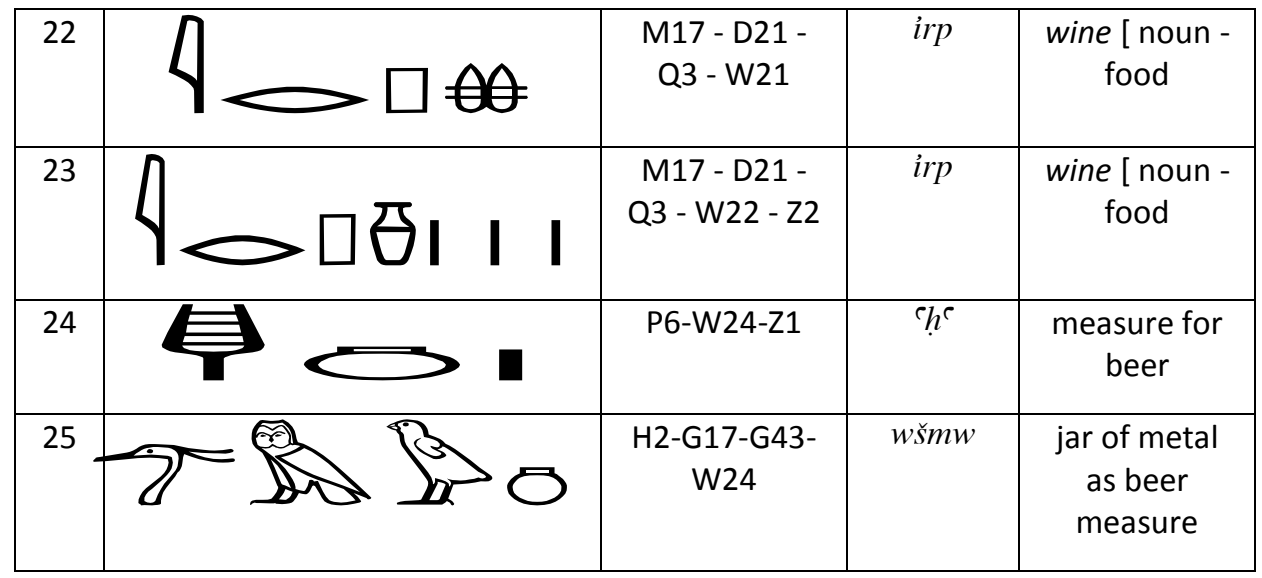

